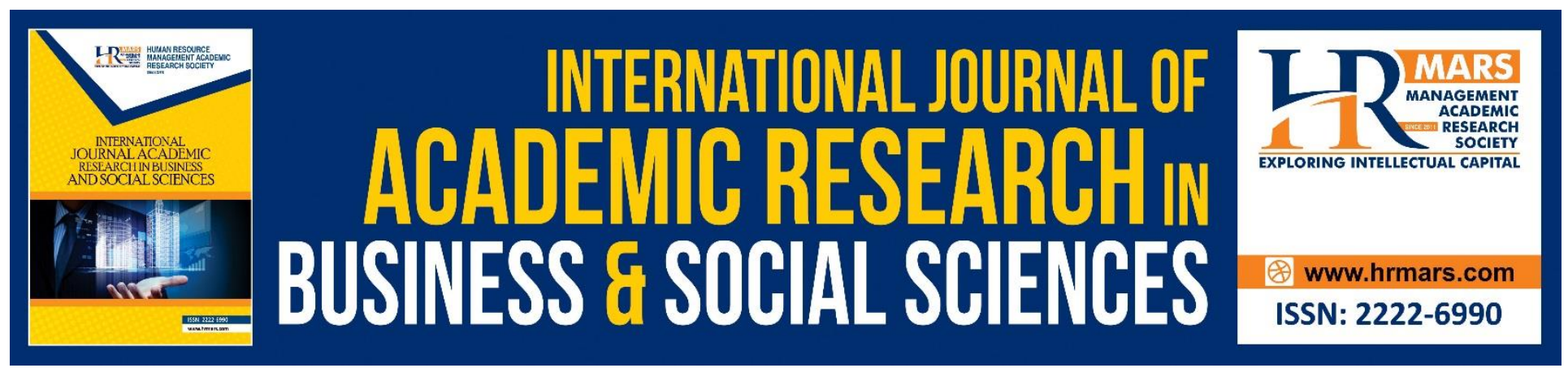

\title{
Discovering Meaning behind Consumer Involvement in Counterfeit Consumption Behaviour
}

Nurhidayah Rosely, Raja Nerina Raja Yusof, Haslinda Hashim, Nor Azura Adzharuddin

To Link this Article: http://dx.doi.org/10.6007/IJARBSS/v9-i1/5484

DOI: $\quad 10.6007 /$ IJARBSS/v9-i1/5484

Received: 23 Dec 2018, Revised: 19 Jan 2019, Accepted: 06 Feb 2019

Published Online: 08 Feb 2019

In-Text Citation: (Rosely, Yusof, Hashim, \& Adzharuddin, 2019)

To Cite this Article: Rosely, N., Yusof, R. N. R., Hashim, H., \& Adzharuddin, N. A. (2019). Discovering Meaning behind Consumer Involvement in Counterfeit Consumption Behaviour. International Journal of Academic Research in Business and Social Sciences, 9(1), 830-845.

\section{Copyright: (C) 2019 The Author(s)}

Published by Human Resource Management Academic Research Society (www.hrmars.com)

This article is published under the Creative Commons Attribution (CC BY 4.0) license. Anyone may reproduce, distribute, translate and create derivative works of this article (for both commercial and non-commercial purposes), subject to full attribution to the original publication and authors. The full terms of this license may be seen

at: http://creativecommons.org/licences/by/4.0/legalcode

Vol. 9, No. 1, 2019, Pg. 830 - 845

http://hrmars.com/index.php/pages/detail/IJARBSS

JOURNAL HOMEPAGE

Full Terms \& Conditions of access and use can be found at http://hrmars.com/index.php/pages/detail/publication-ethics 


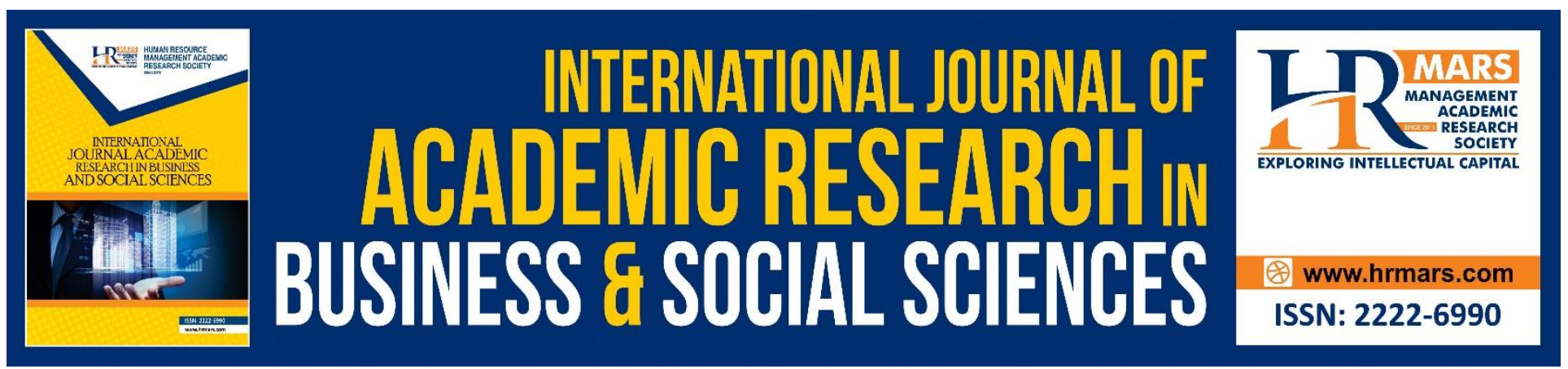

\title{
Discovering Meaning behind Consumer Involvement in Counterfeit Consumption Behaviour
}

\author{
Nurhidayah Rosely, Raja Nerina Raja Yusof, Haslinda Hashim, Nor \\ Azura Adzharuddin \\ Universiti Putra Malaysia, Serdang, Selangor, Malaysia
}

\begin{abstract}
The rising demand on counterfeit goods has led to a new phenomenon in consumer behavior. Counterfeit goods have long been labelled as inferior in quality, and often targeted at consumers with low purchasing power. However, current trends show that there is a rise in the number of consumers who willingly purchase counterfeit goods despite being able to afford the original merchandise. This paper seeks to explain the phenomenon of non-deceptive counterfeit goods demand among Malaysian consumers by analyzing consumer meaning from real life experiences. The concept of consumer rationalization on this unethical practice leads to the construction of meaning behind consumer involvement in counterfeit consumption behavior. This research reveals three themes of meaning behind consumer involvement namely: "It's just a fading material object", "It's just the right time" and "I need to protect it". This research is also one of the few studies that identify the meaning behind consumer involvement in counterfeit consumption from the perspective of the consumers' real-life experience. This paper contributes to the scholarly and managerial fields specifically in the Malaysian context by providing more insights into this phenomenon.
\end{abstract}

Keywords: Counterfeit Consumption Behavior, Meaning, Rationalization, Motivation, Cognitive Dissonance Theory

\section{Introduction}

Counterfeit goods are one of the most persistent issues in the industry that has remained unresolved despite deliberations for over a decade, and authentic goods manufacturers are still searching for a solution to prevent the development of the counterfeit market. Billions of dollars in losses have been borne by the manufacturers of luxury goods (Bekir, El, \& Gilles, 2013; Bian \& Moutinho, 2009; Bian, Wang, Smith, \& Yannopoulou, 2016; Eisend \& Schuchert-güler, 2006; Staake, Thiesse, \& Fleisch, 2009) due to the substitution effects created by the counterfeit market that devalued the brand images of authentic goods. Manufacturers of authentic goods have invested heavily on research and development, technology, and brand equity management in order to gain a lucrative return on their investment (Cesareo \& Stöttinger, 2015). However, this scenario has turned 
INTERNATIONAL JOURNAL OF ACADEMIC RESEARCH IN BUSINESS AND SOCIAL SCIENCES Vol. 9, No. 1, Jan, 2019, E-ISSN: 2222-6990 (C) 2019 HRMARS

into a liability for the manufacturers as irresponsible counterfeiters have seized the available opportunities by creating demands for another market (Meraviglia, 2015).

Consumer demand is the leading cause of the development of counterfeit markets and poses the greatest challenge for authentic fashion goods manufacturers as well as governments in preventing consumer involvement in counterfeiting activities. Consumer involvement is a major concern for researchers, and in recent years, there has been extensive research on consumer involvement in counterfeit purchases (Eisend \& Schuchert-güler, 2006).

Counterfeiting could be defined as any unauthorized manufacturing of original products (Bian $\&$ Veloutsou, 2007) with remarkable brand values that have been copied and sold at a lower price (Eisend \& Schuchert-güler, 2006). Counterfeit fashion goods are also synonymous with terms such as replicas, knock-offs, fakes, high grade, "inspired by", bogus, and imitation all of which carry similar characteristics and are indistinguishable from the genuine version of the goods (Staake, Thiesse \& Fleisch, 2012).

\section{Literature Review \\ Counterfeit Consumption}

Numerous studies have attempted to explain consumer involvement in counterfeit purchase according to different contexts of consumer knowledge: deceptive counterfeit purchase or nondeceptive counterfeit purchase (Phau, Sequeira, \& Dix, 2013; Staake et al., 2009). Building from these studies, non-deceptive counterfeit purchase attempts to explain the phenomenon of consumer demand for counterfeit goods. As consumers are aware and knowledgeable enough to distinguish between counterfeit and genuine goods, consumer attitudes and behaviours become the major determinant to the survival of the counterfeit market (Eisend \& Schuchert-güler, 2006; Meraviglia, 2015; Phau et al., 2013).

Due to this motivation, a growing body of literature has investigated the consumer's willingness to purchase counterfeit goods by identifying several influential factors that motivate consumer attitudes and purchase intentions. In order to investigate the rising demand for counterfeit goods, studies need to be carried out to explore the causes and reasons behind consumer involvement in counterfeit purchases (Bian et al., 2016). Therefore, the notion of non-deceptive counterfeit purchases is the most appropriate context to be used as consumers voluntarily engage in this unethical behaviour.

The study on counterfeit goods purchase revolves around the negative perception and beliefs on the quality and benefits of using counterfeit goods that are turned into positive beliefs, initially by consumers with low purchasing power (Amaral \& Loken, 2016a; Staake et al., 2009; Zaichkowsky, 2000). In fact, the quality of the manufactured counterfeit goods and the positive acceptance by the social group members had changed the evolution of the counterfeit goods market (Cesareo \& Stöttinger, 2015). The purchasing of counterfeit goods is not only for satisfying the consumers' utility needs, but also for the expected fulfillment of the consumers' hedonic needs such as the feelings of 
pleasure, fun and excitement (Bian et al., 2016; Quintanilla, Perez, \& Castan, 2010; Romani, Gistri, \& Pace, 2012).

Consumers usually try to rationalise their purchase decision by changing their existing beliefs and attitudes towards some events in order to meet the inconsistencies. As found in prior studies, consumers are willing to purchase counterfeit goods due to the perception that their actions will not harm any individual, the society and manufacturers of genuine luxury goods (Cesareo \& Stöttinger, 2015). These consumers also gain strong support from other social group members who purchase counterfeit goods (Key, Jr, Adjei, \& Campbell, 2013; Thaichon \& Quach, 2016) although they are aware that such behaviour is unethical and illegal (Bian et al., 2016; Eisend \& Schuchert-güler, 2006; Pueschel, Chamaret, \& Parguel, 2016).

These consumers also try to alter their existing beliefs and attitudes towards counterfeit purchases by eliminating the feelings of guilt. They are motivated to keep giving excuses to justify their involvement in counterfeit goods purchases. This finding was also supported by Kim (2014) who reported that consumers try to decrease the importance of dissonance cognition by convincing themselves that they are wiser spenders for optimizing the available resources deemed as a good investment for something that degenerates easily.

Contrary to previous studies, Phau, Sequeira \& Dix (2009) revealed that consumers always try to reduce the discrepancy between immoral and moral purchasing by excusing themselves from violating their personal judgment on counterfeit goods. Apparently, this study was supported by Bian et. al. (2016) who discovered that consumers often try to compensate their unethical consumption behaviour and eliminate unpleasant feelings by rationalising their purchase decisions.

In fact, consumers often try to rationalize that what they have purchased is worthy as long as the counterfeit version satisfies their hedonic and utility needs (Key et al., 2013; Kim \& Johnson, 2014; Pueschel et al., 2016; Thaichon \& Quach, 2016). Bian et. al. (2016) further reported that consumers rationalize their involvement in counterfeit consumption through two neutralization techniques namely denial of responsibility and appealing to higher loyalties which function as coping strategies to eliminate the feeling of dissonance. This reinforces the consumers' motivation to sustain their consumption practice and involvement in counterfeit consumption behavior due to their mental ability to alter the negative cognition and dissuade the feeling of dissonance.

These consumers purchase counterfeit goods to accomplish several goals and psychological needs such as self-esteem, status and social needs (Amaral \& Loken, 2016a; Ar, 2012; Peng, Wan, \& Poon, 2013; Phau, Teah, \& Chuah, 2015; Quintanilla et al., 2010). The inability to attain goals through genuine material objects leads to the feelings of self-frustration and disappointment. As the attainment of goals leads to the feeling of life satisfaction, consumers try to attain that feeling through easily achievable goals (Pugno, 2008) in the form of counterfeit fashion goods and try to convince themselves that counterfeit goods are really worth it, enjoyable, and fun to use (Pueschel et al., 2016; Quintanilla et al., 2010). 
Throughout the widespread literature on counterfeit goods purchase, only a few studies have used the Theory of Cognitive Dissonance (Festinger, 1957) to explain how and why consumers are involved in counterfeit consumption behaviour. Prior studies on counterfeit goods purchase indicate cognitive dissonance as motivational drivers and how consumers rationalize their involvement in counterfeit goods. Eisend (2006) explained the phenomenon of counterfeit goods demand from the perspective of motivation through cognitive dissonance. The authors discussed how consumers are urged to modify their existing cognitions of counterfeits and meeting the inconsistencies between both cognition and behaviour. This theoretical study had opened up a new avenue for other scholars to explore other dimensions on consumer motivations through the rationalization of behaviour.

The empirical study conducted by Sharma \& Chan (2014) utilized the theory of cognitive dissonance in developing a conceptual framework and explaining the role of product evaluation as the mediating factor between subjective norms, ethical judgment as a factor and counterfeit proneness that influences consumer purchase intentions. Surprisingly, this finding revealed that Chinese consumers in China are not concerned anymore with the "face consumption" that previously had a negative influence on consumer purchase intention on counterfeit goods (Chen, Zhu, Le, \& Wu, 2014; Pang, 2008). Subjective norms encourage the Chinese consumers' willingness to purchase counterfeits, as it has become an acceptable norm among social group members in China. The consumers hence have the opportunity to showcase their counterfeit fashion goods in public without the fear of exposing themselves to negative social repercussions. This explains the tremendous market demand for counterfeit goods as consumers are able to change their existing negative beliefs and justify their consumption behavior with several temporary benefits.

Bian et al. (2016) revealed that these consumers come out with cognitive, moral logics and neutralization techniques to justify their involvement in counterfeit consumption. Together, this study provides important insights into the literature as hedonic and emotional outcomes contribute much as the motivational drivers that help consumers rationalize their involvement in this unethical behavior. The result in this study indicates that counterfeit consumption created an opportunity to demonstrate consumer expertise and knowledge besides satisfying hedonic needs from the emotional experience. Meanwhile, Pueschel et al. (2016) utilized the cognitive dissonance theory to ascertain how the consumers come out with several risk perceptions in order to cope with the uncertain psychosocial risks. The finding points out that the affluent consumers utilize the availability of counterfeit goods and demonstrate their skills and knowledge to reduce the risks. Surprisingly, Islamic consumers use religious and moral values to excuse themselves and to rationalize their consumption behavior. This indicates that these consumers are taking prior steps and strategies to minimize the risks of dissonance to escape the psychological conflict.

\section{Meaning on Counterfeit Consumption}

In a post-modern consumption era, consumers try to relate their consumption activities with self-concept, image and identities (Elliott, 2006; Piacentini \& Mailer, 2004; Tian \& Belk, 2011). Each decision to engage in any consumption activity is purposive and goal-oriented as consumers believe it will communicate meaning to the society. Therefore, consumers should carefully select their 
activities including the decision to be involved in any consumption behavior (Kasser \& Ryan, 2001; Pugno, 2008; Truong, McColl, \& Kitchen, 2010). Consumers believe that the consumption of material goods construct personal meanings that can later be related to their lives. Those meanings which are subjective will guide their consumption behaviour and explain the reasons for consumer involvement in any specific activities.

The aforementioned studies started with investigations on consumer motivation behind counterfeit consumption behaviour and later directed to different paths and objectives. Bian et al. (2016) concluded their study with neutralization techniques to cope with unethical consumption and found possible benefits and consequences that consumers may gain from their involvement. Whereas, Pueschel et al. (2016) finalized their study with several strategies to cope with the perceived risks from consumer involvement in counterfeit consumption. While both studies provided interesting insights, there is a lack of emphasis on the meaning of counterfeit consumption from the angle of emotional experiences via cognitive dissonance. Cognitive dissonance is able to connect emotional experiences to find the meaning behind consumer involvement in counterfeit consumption. This implies that the internal conflict between guilt and pleasure could derive a meaning from the subjective experiences in counterfeit consumption behaviour. Bian et al. (2016) found two contrasting emotional experiences from the outcomes of neutralization techniques. This study intends to extend the search to find the meaning behind the consumers' involvement through rationalization strategies.

Although cognitive dissonance allows consumers to rationalize their purchase decision, the role of affective and emotion are also important in consumption behaviour as discovered in hedonic consumption (Alba \& Williams, 2012; Yim, Yoo, Sauer, \& Seo, 2014) and luxury brand consumption (Kastanakis \& Balabanis, 2012; Morrin, 2010). The rationalization of counterfeit goods usage will be more meaningful if it is derived from consumer emotional and functional experiences; therefore, new insights will be discovered to explain consumer involvement in non-deceptive counterfeit goods purchase. Moon, Javaid, Kiran, Awan, \& Farooq (2018) identified that hedonic and utilitarian attitudes act as an organism that influences consumer purchase intention in the context of counterfeit goods. The finding reveals that hedonic attitudes which stem from emotional values act as the main drivers that urge consumer purchase intention rather than utilitarian attitudes. Therefore, it is suggested that the integration of cognitive and affective elements in investigations from the angle of emotional experiences (guilt and pleasure) should be explored further to understand the consumers' meaning behind their involvement in counterfeit consumption behaviour. A meaningful insight will be discovered through the consumers' real life experiences which therefore will explain the reason behind the consumers' involvement in this unethical consumption behavior. Specifically, this study addresses the following questions that have not yet been fully explored.

What is the meaning of counterfeit consumption behavior to Malaysian consumers? How do Malaysian consumers rationalize their involvement in counterfeit consumption behavior? 


\section{Methods}

Given the exploratory nature of the study, phenomenology is applied to understand the meaning behind consumer involvement in counterfeit consumption behavior. Phenomenology provides more insights from the actual consumers' real-life experiences (Merriam, S. \& Tisdell, E. (2016) and thus able to explain about the increasing demand on counterfeit goods from the consumers' continuous involvement. In-depth interviews are "directed towards understanding informants' perspectives on their lives, experiences as expressed in their words" (Taylor \& Borgan, 1984, p. 77) and statements that infuse meaning (Silverman, 2011). By allowing the informants to talk freely about their consumption experience with counterfeit goods, a semi-structured interview was conducted.

The Malaysian marketplace was chosen as the context of study because Malaysia is one of the countries in Southeast Asia that has been aggressively attacked by counterfeiters and has become an ideal transit hub for counterfeiting activities (Chui, 2017). Apart from that, the level of awareness among Malaysian consumers on protecting intellectual properties right is still unsatisfactory rendering the need to conduct more research on this illicit trade of counterfeit goods in Malaysia (The Edge Financial Daily, 2018).

The researcher conducted 10 in-depth interviews with Malaysian consumers ranging from 20 to 35 years old. The informants should have at least 2 years' experience purchasing and using counterfeit fashion goods i.e. actively purchasing, owning and using counterfeit goods for the past six months. This criterion is important in defining consumer involvement (Fredman, 1964) as well as interest, concern and commitment (Howard \& Seth, 1969) particularly in counterfeit consumption activities that are fit to be described as non-deceptive counterfeit purchases. In this research, fake fashion goods ranging from apparels, shoes, handbags, women's scarves as well as fashion accessories such as watches and glasses will be referred to as counterfeit fashion goods. Each indepth interview was audio-taped and lasted between 20 to 45 minutes. The researcher began by identifying each consumer who fulfilled the requirements. Then, using the snowball method, the consumers were asked to recommend other possible candidates. Each participant received RM50 cash as a token of participation.

\section{Findings}

From 10 verbatim transcripts, 127 significant statements were extracted, 11 formulated meanings which were then arranged into clusters resulting in 3 themes of counterfeit consumption behavior meanings. These themes are: "It's just a fading material object", "Well, it's just the right timing!" and "I need to protect it".

\section{Theme 1: It's just a fading material object!}

A common reason shared by most of our informants regardless of their socio-demographic profile was the quality and money-worthiness of their purchase. Although most of the informants are fully-aware of the fact that counterfeit goods are lesser in quality as compared to genuine fashion 
INTERNATIONAL JOURNAL OF ACADEMIC RESEARCH IN BUSINESS AND SOCIAL SCIENCES

Vol. 9, No. 1, Jan, 2019, E-ISSN: 2222-6990 (C) 2019 HRMARS

goods, they are willing to compromise on that aspect. For them, the counterfeit market provides a cost-saving platform apart from the notion that counterfeit goods have subjective values:

Since the quality of the material is similar, why should we buy the original one, if we could save our money on it (Joe, 33).

I just buy when it is necessary for me to buy. Such as sports shoes, the original price is around RM400 to RM500, but if we can find similar shoes that only cost RM60, RM70 with the same design, it's better to buy those instead. Although they might not be as comfortable as the original ones, for me, it's just fine to wear (Jas, age 22).

Some of the informants believe that instead of spending excessive amounts of money on genuine fashion goods, it is better to buy the counterfeit version overseas which promises better quality and of which reinforces their rationalization of being a wise consumer. Furthermore, the purchasing of genuine fashion goods often leads to post-purchase dissonance due to the rapidly changing fashion trends and designs that trigger wastefulness:

When we look at high grade counterfeit goods from Hong Kong, we can see that the quality of the leather material and workmanship is too fine. It's the exact copy of the original version. So why should we waste our money buying the original one. It is better to buy the high grade version. Yes, fashion is a trend. So year after year, people will change to a new one. So we shouldn't waste a lot of money buying the original one; it is better for us to buy the copy version. I will regret buying the original one because I had to spend a lot of money on it. With the high grade version, there will be no regrets once the goods are spoiled or worn out. So it's worth although I have to go overseas to buy the high grade version (Gina, age 33).

Most of the informants said that counterfeit fashion goods deliver identical and mirror image of the original versions, which drives them to be involved in counterfeit consumption behavior. Although they know that the value of satisfaction derived from counterfeit goods is less exquisite than the original versions, the chance to have that temporary feeling is enough to drive them to buy fake merchandises. The informants do not regard it as a sense of disappointment, but rather a chance to have a similar experience as the original goods consumers, which explains why they do not mind the short-term satisfaction:

I just feel that someone who comes from a wealthy background will gain $100 \%$ satisfaction from the goods that they had bought. But as for us who can only afford to buy copy-ori goods, we only gain a quarter from that $100 \%$ satisfaction. That's my feeling, as long as I can wear it, that's enough. We need to look into our capability, right? So if we want to try and wear it, it's fine (Jas, age 22). 


\section{Theme 2: Well, it's just the right timing!}

One of the interesting factors that drive counterfeit consumption is the unavailability of the genuine versions of the fashion goods. Most of the informants said that the limited access to purchase original brands leads to disappointment, which is then substituted with a sense of satisfaction once they find an alternative to purchase and own an identical version of the brands. It could be concluded that counterfeit fashion goods exist at the right time to help consumers satisfy their hedonic and utility needs:

I always buy Naelofar Vietnam version from my colleague with the price of RM100 for 3 pieces. I bought them because each time I wish to buy the new original collections, they will be sold out on their website. It's so annoying. I'm unable to grab them. I feel like I have to buy and own the Naelofar hijab brand. I have needs and the desire to own them (Nad, age 28).

Sometimes, it is quite difficult to buy the original goods because they tend to be sold out too fast. As an example, when Vans Pa'din Musa released his new special collection it was rare For the first launching, they only launched 100 pairs of shoes. It was very limited Then, the premium copy became available in the market ............... The timing of release between the original and premium copy was too close, people didn't realize they were the copied versions. People will think that we are wearing the original ones. Otherwise, I still don't have any problem with it (Hadi, age 22).

Apparently, both the abovementioned quotes describe situational factors that drove the informants to look for other convenient and more accessible alternatives to satisfy their needs. The strategy of wanting to be "exclusive" by the original fashion goods had incidentally opened up new opportunities for both the counterfeiters and the consumers.

One of the informants said that genuine fashion goods tend to "discriminate" oversized consumers since the brands only produce goods in limited sizes which create internal tense among consumers to own the original fashion goods. Therefore, substituting their needs with counterfeit versions was the best option. They also gain more value by buying identical designs at a cheaper price:

Malaysia always discriminates oversized people like me. When I buy from the boutique, the largest size available was only XXL, which does not exactly fit XXL-sized people. My size is not available there. Based on Malaysian standards, oversized people like me will have no chance of wearing the boutique brand. However, if we buy the copy version from outside, it is based on American size which fits oversized people (Joe, age 32). 
A majority of the informants said that aesthetic values such as design and colors urge them towards impulse buying leading to their continuous involvement in counterfeit consumption. Some of the informants indicate situational factors and impulsiveness as the drivers behind their counterfeit fashion goods consumption apart from the practicality of the design. Although they are aware of the lesser quality goods, they are still willing to buy them for the sake of owning merchandises that are identical to original brands. They are satisfied with the aesthetic values of the counterfeit fashion goods:

I do not purchase copy-ori goods frequently, but if I wish to have a designer brand, I will buy the copy-ori version. I buy fake merchandises because their designs are nice. I am aware that I can't afford authentic brands, but I have the desire to own similar designs. I could say that this is due to the trend (Jas, age 22).

I felt satisfied buying it because of the design and practicality. I love Long Champ's design because it can fit and store a lot inside (Syaza, age 32).

I bought the copy-ori shoes because of the design and not because of the trend. I collect jerseys because of the nice designs. When the season ends, the design that I admire will no longer be available so I have to buy it (Luqman, age 21).

I prefer buying jerseys of powerful clubs due to the nicer designs as compared to ordinary T-shirts. The club name and logo are the selling points for me. The material is also suitable for leisure and sports (Hakim, age 21).

Based on the informants' description of their involvement in counterfeit consumption behavior, it is found that the scarcity effect in terms of the unavailability of the genuine fashion goods and financial incapability are the drivers that urge them to find other alternatives to own and possess those material goods. With the right time and situational factors, counterfeiters were wise in utilizing this opportunity to provide similar consumption experiences and satisfaction as genuine fashion goods. Almost all of the informants enjoyed and willing to sustain their involvement in this counterfeit consumption behavior as they found more hedonic and functional values which are worthy of the money that they had spent.

\section{Theme 3: I need to protect it!}

Surprisingly, some of the informants sustain their involvement in counterfeit consumption because of the need to protect their ownership of genuine fashion goods. Dual consumption with dual motives became the motivation for the informants to keep purchasing counterfeit goods. Prior literature mentioned that consumers mix their purchase and usage of genuine luxury and counterfeit goods to protect their social hierarchy and manipulate the other social groups (Amaral \& Loken, 2016b; Pueschel et al., 2016). However, in this study, the informants use the counterfeit goods to protect the genuine versions and use both according to the occasion and situation: 
As for me, I buy copy-ori because if I wear the original for daily use such as for work, it will be too wasteful. Am I right? I prefer to keep the original one in the closet, in the box, wear it while hanging out with friends, shopping and going for holidays (Hadi, age 22).

I have bought both original and copied shoes. As for daily usage such as going to class and the workshop, I prefer to wear the copied one. Because of safety purposes in a workshop, I need to wear the copied one. There was one time when I had to wear my copied Vans because some oil had spilled on my original Vans during my workshop class. I felt that I should wear the copied one to protect my original Vans.

I wore 3 pairs of copied Vans shoes throughout my 3 years in university The original one I only wear for leisure, but the copied version I wear to class and the workshop. I love my original shoes and feel that it's a waste to wear it for daily usage (Zahid, age 22).

Note that in the second quote, the informant indicated a strong sense of attachment to his genuine goods. As a result, he was motivated to find an alternative merchandise to protect the value of his original branded shoes. Thus, the informant sustains his involvement in counterfeit consumption as a way to protect his genuine goods.

Another informant also has the same agenda which is to protect the value of his genuine goods. The informant believes that keeping the original version in good condition is a smart investment for the future and a smart way of keeping up with the latest trends:

But then, I'll try to search for the fake one just to wear it. However, I'll upload the photo of the original merchandise on social media to show off to others. As for the fake version, l'll wear it. Because I believe the price of the original one will rise in the future. I will have the original one for my personal collection and the fake one too (Joe, age 32).

The quote illustrates that the informant is willing to spend some extra money purchasing both versions as he found that counterfeit market provides a platform for him to satisfy his hobbies and interest. The informant voluntarily spends his time, money and effort to evaluate and select the best counterfeit version to replace the genuine one as he believes both versions are important for him and gives him satisfaction. This suggests that counterfeit consumption not only satisfies the functional and material needs of the consumer, but also help the informant to fill his free time with meaningful activities.

\section{Discussion and Conclusion}

This exploratory study sets out to gain more insight in understanding consumer involvement in counterfeit consumption behavior, specifically in searching for the meaning from the perspective of the consumers' real life experiences. Previous studies have stated that consumers try to "excuse" 
their involvement in counterfeit goods purchasing by altering their existing beliefs and perceptions on counterfeits. The rationalization process through cognitive dissonance enables the consumers to justify their involvement in this unethical consumption using several coping strategies to escape from guilt (Bian et al., 2016) and coming out with possible strategies of perceived risks to deal with unexpected consequences (Pueschel et al., 2016). Similarly, in this study, the consumers give meaning to their involvement in counterfeit consumption through a rationalization process according to their consumption experience. Three themes of meaning emerged and Malaysian consumers are obviously not concerned with either image, social reputation or moral issues when engaging in this unethical consumption behavior.

The first theme illustrates that consumers are not willing to sacrifice much money on material objects for temporary usage. As fashion goods are concerned with trends and style which easily fade (Lisa, Turunen, Lisa, \& Turunen, 2015), consumers found counterfeit goods as the best alternative to keep up with trends without having any post-purchase dissonance on spending too much money. As technological advancement helps counterfeiters to duplicate high quality genuine goods (Cesareo \& Stöttinger, 2015) with similar aesthetic values, consumers feel more satisfied with the cost they had paid and are able to compromise with any risks posed by the counterfeit versions. They are fully conscious and aware that the satisfaction of owning and using counterfeit goods are far behind that of genuine fashion goods, but they rationalize their purchase decision by justifying that it is not worth it to invest much on material objects that easily fade. This justification helps consumers to define their involvement in counterfeit consumption as meaningful activities in their life. With their involvement in counterfeit consumption, consumers feel wiser for utilizing the opportunity to satisfy their hedonic and functional needs without feeling out of trend. After all, the value and satisfaction they gained from the counterfeit goods is sufficient for them to rationalize their consumption behavior and to sustain their involvement in this illicit consumption behavior.

Surprisingly in this study, post-purchase dissonance related to genuine fashion goods causes the consumers more regret than post-purchase dissonance related to counterfeit goods which is in complete contrast with the results of prior studies (Bian et al., 2016; Kim \& Johnson, 2014; Pueschel et al., 2016). Malaysian consumers are prone to disregard the possible consequences towards themselves for purchasing and using counterfeit goods because the emotional experiences such as enjoyment, fun and happiness while doing so construct a meaning and definition for their counterfeit consumption behavior. Affective and emotional elements as found in other hedonic and luxury brand consumption (Alba \& Williams, 2012; Kastanakis \& Balabanis, 2012; Morrin, 2010; Yim et al., 2014) play an important role in altering the consumers' cognition which allows the consumer to rationalize their purchase decision and involvement in any consumption behavior.

The second theme indicates that counterfeit goods exist at the right time and situation whenever the consumers feel the urge to fulfill their utility and hedonic needs. Such needs cannot be satisfied by genuine fashion goods due to their limited access whilst the scarcity effect created by the genuine goods "discriminate" those who are craving to own genuine brands. Therefore, counterfe it fashion goods indirectly created the opportunity for consumers to fulfill their aforementioned desires 
INTERNATIONAL JOURNAL OF ACADEMIC RESEARCH IN BUSINESS AND SOCIAL SCIENCES

Vol. 9, No. 1, Jan, 2019, E-ISSN: 2222-6990@ 2019 HRMARS

at the right time. Although consumers are aware that counterfeits are often low in quality, the fake goods contribute much value and satisfaction to them nonetheless.

The third and final theme entails counterfeit goods acting as protection tools for their genuine fashion goods. Due to the strong sense of attachment to their genuine merchandise, the consumers found that the counterfeit versions with similar physical features can replace the function of their genuine goods whereby the fake versions can be used on a daily basis without needing much protection and care. The dual motives and consumption motivate the consumers to purchase both versions and then sustain their involvement in counterfeit consumption behavior. This finding differs from prior studies whereby most of the consumers purchase both versions of goods with the purpose of social status manipulation (Amaral \& Loken, 2016b; Kim \& Johnson, 2014; Pueschel et al., 2016). Consumers are much more concerned about the investment they made on genuine fashion goods and therefore to protect it, they use counterfeit versions to reduce the sense of dissonance which is focused more on internal satisfaction rather than social approval and acceptance. This finding reveals that Malaysian consumers put more emphasis on their inner needs rather than social needs.

The findings suggest that counterfeit consumers are actively involved without thinking much about the social consequences; they rationalize their consumption behavior as something socially acceptable and common. The informants describe counterfeit fashion goods as being "far behind" genuine fashion goods in terms of quality, price and satisfaction, but ultimately resolve cognitive dissonance (Festinger, 1957) by framing counterfeits as an alternative that delivers positive benefits such as value consciousness, and being mirror images of genuine fashion goods. Thus, they appear to attribute their involvement in counterfeit consumption as a wise choice to protect their genuine material objects, gaining short-term satisfaction in keeping ahead with the trend. The meaning of counterfeit consumption is much more favorable as hedonic and positive emotional experiences framing the definition of counterfeit consumption behavior. As found by Moon et al. (2018), hedonic and emotional values significantly act as the main drivers of consumer purchase intention rather than utilitarian attitudes. This explains why and how consumers are able to rationalize the existing negative cognition of counterfeit goods with positive emotional experience that they gain through the consumption process. The emotional experiences deliver much more benefits to the consumers and motivate them to sustain their involvement in counterfeit consumption without thinking much about the possible social consequences.

The present work intends to open up a new avenue to inspire a new perspective in the realm of counterfeit studies specifically in Malaysia. Looking at the level of Malaysian consumer awareness on this issue, there is little doubt that counterfeit consumption will continue as a serious problem for legitimate firms. Although we had foreseen the difficulty in convincing counterfeit consumers to share their consumption experiences and thoughts, an alternative ethnographic or netnographic method among teenagers should be conducted in future studies to understand the counterfeit community better. As intellectual property rights are important to Malaysia's economy, targeting youngsters and teenagers as the respondents is important to create and enhance awareness among them in order to protect Malaysia's future economy. Furthermore, characteristics such as 
INTERNATIONAL JOURNAL OF ACADEMIC RESEARCH IN BUSINESS AND SOCIAL SCIENCES

Vol. 9, No. 1, Jan, 2019, E-ISSN: 2222-6990 (C) 2019 HRMARS

impulsiveness as found in this study could be further explored as underlying factors that motivate consumer involvement in counterfeit consumption behavior.

\section{Acknowledgement}

This research was partially requirement for Doctorate Philosophy Degree with the supervision of Dr. Raja Nerina Raja Yusof, Dr. Haslinda Hashim from Faculty of Economics and Management, Universiti Putra Malaysia and Dr. Nor Azura Adzharuddin, Faculty of Modern Language and Communication, Universiti Putra Malaysia.

\section{Corresponding Author}

Nurhidayah Rosely can be contacted at: hidayahrosely@yahoo.com, Faculty of Economics and Management, Universiti Putra Malaysia, Serdang Selangor, Malaysia.

\section{References}

Alba, J. W., \& Williams, E. F. (2012). Pleasure principles : A review of research on hedonic consumption. Journal of Consumer Psychology. http://doi.org/10.1016/j.jcps.2012.07.003

Amaral, N. B., \& Loken, B. (2016a). ScienceDirect Viewing usage of counterfeit luxury goods : Social identity and social hierarchy effects on dilution and enhancement of genuine luxury brands. Journal of Consumer Psychology, 26(4), 483-495. http://doi.org/10.1016/j.jcps.2016.02.004

Amaral, N. B., \& Loken, B. (2016b). Viewing usage of counterfeit luxury goods: Social identity and social hierarchy effects on dilution and enhancement of Genuine Luxury Brands. Journal of Consumer Psychology. http://doi.org/10.1016/j.jcps.2016.02.004

Ar, A. R. (2012). Counterfeit Luxury Goods Online: An Investigation of Consumer Perceptions. International Journal of Marketing Studies, 4(2), 74-79. http://doi.org/10.5539/ijms.v4n2p74

Bekir, I., El, S., \& Gilles, H. (2013). How a luxury monopolist might benefit from the aspirational utility effect of counterfeiting ?, 169-182. http://doi.org/10.1007/s10657-011-9235-x

Bian, X., \& Moutinho, L. (2009). An investigation of determinants of counterfeit purchase consideration. Journal of Business Research, 62(3), 368-378. http://doi.org/10.1016/j.jbusres.2008.05.012

Bian, X., \& Veloutsou, C. (2007). Cnsumers' attitudes regarding non-deceptive counterfeit brands in the UK and Chinao. Journal of Brand Management, 14(3), 211-222. http://doi.org/10.1057/palgrave.bm.2550046

Bian, X., Wang, K.-Y., Smith, A., \& Yannopoulou, N. (2016). New insights into unethical counterfeit consumption. Journal of Business Research. http://doi.org/10.1016/j.jbusres.2016.02.038

Cesareo, L., \& Stöttinger, B. (2015). United we stand, divided we fall: How firms can engage consumers in their fight against counterfeits. Business Horizons, 58(5), 527-537. http://doi.org/10.1016/j.bushor.2015.05.007

Chen, Y., Zhu, H., Le, M., \& Wu, Y. (2014). The effect of face consciousness on consumption of counterfeit luxury goods. Social Behavior and Personality, 42(22), 1007-1014.

Chui, C. B. (2017). The Counterfeit Goods Conundrum : An Analysis Of Demand Situation Among Malaysian Consumers, 2(2), 11-19.

Eisend, M., \& Schuchert-güler, P. (2006). Explaining Counterfeit Purchases : A Review and Preview, 
INTERNATIONAL JOURNAL OF ACADEMIC RESEARCH IN BUSINESS AND SOCIAL SCIENCES

Vol. 9, No. 1, Jan, 2019, E-ISSN: 2222-6990 @ 2019 HRMARS

2006(12).

Elliott, R. (2006). Existential consumption and. European Journal of Marketing, 31(3/4), 285.

Kang, S. L., \& Wong, E. L. (2018, April 2). Sales of fake goods hits alarming level. The Edge Financial Daily. Retrieved from http://www.theedgemarkets.com/article/sale-fake-goods-hits-alarminglevel.

Kasser, T., \& Ryan, M. (2001). Be Careful What You Wish For: Optimal Functioning and the Relative Attainment of Intrinsic and Extrinsic Goals.

Kastanakis, M. N., \& Balabanis, G. (2012). Between the mass and the class: Antecedents of the "bandwagon" luxury consumption behavior. Journal of Business Research, 65(10), 1399-1407. http://doi.org/10.1016/j.jbusres.2011.10.005

Key, T. M., Jr, R. E. B., Adjei, M. T., \& Campbell, D. A. (2013). Watch out : Themes in timepiece communities of counterfeit consumption, 317(June), 307-317. http://doi.org/10.1002/cb

Kim, J., \& Johnson, K. (2014). “Shame or pride?" European Journal of Marketing, 48(7/8), 14311450. http://doi.org/10.1108/EJM-02-2013-0110

Lisa, L., Turunen, M., Lisa, L., \& Turunen, M. (2015). fashion brands, 64(2), 119-138.

Meraviglia, L. (2015). Counterfeiting, fashion and the civil society. Journal of Fashion Marketing and Management: An International Journal, 19(3), 230-248. http://doi.org/10.1108/JFMM-062013-0084

Merriam, S. \& Tisdell, E. (2016). Qualitative Research: a guide to design and implementation San Francisco, Calif. : Jossey-Bass.

Moon, M. A., Javaid, B., Kiran, M., Awan, H. M., \& Farooq, A. (2018). Consumer perceptions of counterfeit clothing and apparel products attributes. Marketing Intelligence and Planning, 36(7), 794-808. http://doi.org/10.1108/MIP-11-2017-0272

Morrin, M. (2010). Why buy luxury? insights from consumer research, 224-241.

Pang, L. (2008). 'China Who Makes and Fakes': A Semiotics of the Counterfeit. Theory, Culture \& Society, 25(6), 117-140. http://doi.org/http://dx.doi.org/10.1177/0263276408095547

Peng, L., Wan, L. C., \& Poon, P. S. (2013). Responses to Counterfeit Products.

Phau, I., Sequeira, M., \& Dix, S. (2009). Consumers' willingness to knowingly purchase counterfeit products. Direct Marketing: An International Journal, 3(4), 262-281. http://doi.org/10.1108/17505930911000865

Phau, I., Sequeira, M., \& Dix, S. (2013). Consumers' willingness to knowingly purchase counterfeit products. Dlrect Marketing: An International Journal, 3(4), 262-281. http://doi.org/10.1108/17505930911000865

Phau, I., Teah, M., \& Chuah, J. (2015). Consumer attitudes towards luxury fashion apparel made in sweatshops. Journal of Fashion Marketing and Management, 19(2), 169-187.

http://doi.org/10.1108/JFMM-01-2014-0008

Piacentini, M., \& Mailer, G. (2004). Symbolic consumption in teenagers clothing choices. Journal of Consumer Behaviour, 3(3), 251-262. http://doi.org/10.1002/cb.138

Pueschel, J., Chamaret, C., \& Parguel, B. (2016). Coping with copies: The influence of risk perceptions in luxury counterfeit consumption in GCC countries. Journal of Business Research, 77, 184-194. http://doi.org/10.1016/j.jbusres.2016.11.008

Pugno, M. (2008). Economics and the self: A formalisation of self-determination theory. Journal of 
INTERNATIONAL JOURNAL OF ACADEMIC RESEARCH IN BUSINESS AND SOCIAL SCIENCES Vol. 9, No. 1, Jan, 2019, E-ISSN: 2222-6990 (C) 2019 HRMARS

Socio-Economics, 37(4), 1328-1346. http://doi.org/10.1016/j.socec.2007.03.004

Quintanilla, C., Perez, E., \& Castan, R. (2010). Constructing identity through the consumption of counterfeit luxury goods. Qualitative Market Research: An International Journal, 13(3), 219235. http://doi.org/10.1108/13522751011053608

Romani, S., Gistri, G., \& Pace, S. (2012). When counterfeits raise the appeal of luxury brands. Marketing Letters, 23(3), 807-824. http://doi.org/10.1007/s11002-012-9190-5

Sharma, P., \& Chan, R. Y. K. (2014). Demystifying deliberate counterfeit purchase behaviour towards a unified conceptual framework. Marketing Intelligence \& Planning, 34(3).

http://doi.org/10.1108/02634501011078138

Silverman, D, (2011). Interpreting Qualitative Data. London, UK: Sage Publications.

Staake, T., Thiesse, F., \& Fleisch, E. (2009). The emergence of counterfeit trade: a literature review. European Journal of Marketing, 43(3/4), 320-349. http://doi.org/10.1108/03090560910935451

Staake, T., Thiesse, F., \& Fleisch, E. (2012). Business strategies in the counterfeit market. Journal of Business Research, 65(5), 658-665. http://doi.org/10.1016/j.jbusres.2011.03.008

Taylor, S., \& Borgan, R. (1984). Introduction to Qualitative Research Methods: The Search for Meanings, New York: Wiley.

Thaichon, P., \& Quach, S. (2016). Journal of Retailing and Consumer Services Dark motivescounterfeit purchase framework : Internal and external motives behind counterfeit purchase via digital platforms. Journal of Retailing and Consumer Services, 33, 82-91. http://doi.org/10.1016/j.jretconser.2016.08.003

Tian, K., \& Belk, R. (2011). Consumption and the meaning of life. Journal of Consumer Behaviour, 10(06), 249-274. http://doi.org/10.1016/S0885-2111(06)10010-1

Truong, Y., McColl, R., \& Kitchen, P. J. (2010). Uncovering the relationships between aspirations and luxury brand preference. Journal of Product \& Brand Management, 19(5), 346-355. http://doi.org/10.1108/10610421011068586

Yim, M. Y. C., Yoo, S. C., Sauer, P. L., \& Seo, J. H. (2014). Hedonic shopping motivation and coshopper influence on utilitarian grocery shopping in superstores. Journal of the Academy of Marketing Science, 42(5), 528-544. http://doi.org/10.1007/s11747-013-0357-2

Zaichkowsky, J. L. (2000). Do counterfeits devalue the ownership of luxury brands ? Journal of Product \& Brand Management, 9(7), 485-497. 